\section{INNOVATIVE IMPLEMENTATIONS IN PAINTING OF TRANSCARPATHIA IN THE FIRST HALF OF XX CENTURY}

\author{
Ihor Lutsenko, \\ https://orcid.org/0000-0003-1608-5742 \\ Art History PhD, Associate Professor, \\ Transcarpathian Academy of Art, \\ Uzhhorod, Ukraine \\ Lutcenko07@gmail.com
}

\section{НОВАТОРСЬКІ ВПРОВАДЖЕННЯ У ЖИВОПИСІ ЗАКАРПАТТЯ ПЕРШОЇ ПОЛОВИНИ ХХ СТОЛІТТЯ}

\author{
Луценко Ігор Вікторович, \\ https://orcid.org/0000-0003-1608-5742 \\ кандидат мистецтвознавства, доцент, \\ Закарпатська академія мистецтв, \\ Ужгород, Україна \\ Lutctnko07@gmail.com
}

\section{Abstract}

The aim of the research. The aim of this article is to find basic principles of creative method for art center of Transcarpathia and innovative implementations in best practices of a cohort of artists who worked in the region. Based on the example of art individuals and analysis of their works an attempt is made to define and highlight their innovative principles. In this context peculiarities of interrelations between European artistic centers and creative environment of Transcarpathia in the first half of the XX century are considered. Methodology of investigation. Using means of comparative characteristic, and methods of comparison and historicism the levers of influence of artistic environment in the Central Europe on regional innovative implementations are considered. Scientific novelty. In the mentioned article separate constituents of processes which lead to interaction of Ukrainian, in particular Transcarpathian and Jewish artistic environment, are considered. Complicated processes of interaction between art centers and the regional art school are clarified. Basic fundamentals for forming innovative ideas in the context of Transcarpathian art development in the first half of XX century are grounded. Main landmarks for development of innovative implementations in the system of visual art of Transcarpathia, in particular painting, are demonstrated. Considering common artistic events in European area several meaningful artistic events are defined, which took place on the territory of the region and beyond its boundaries and which allowed to define main tracks in development of innovative solutions for several artists based on their creative methods.

\section{Анотація}

Мета дослідження - в публікації ставиться мета виявити засадні принципи творчого методу мистецького осередку Закарпаття та новаторські впровадження в напрацюваннях когорти митців, що працювали в регіоні. На прикладі окремих мистецьких постатей та аналізу їх творчих доробків проводиться спроба означити та висвітлити новаторські принципи. В цьому контексті беруться до уваги особливості взаємозв'язків європейських мистецьких центрів та творчого середовища Закарпаття в першій половині XX століття. Методика дослідження. Засобами порівняльної характеристики, методом співставлення та історизму розглядаються важелі впливу мистецького середовища центральної Європи на регіональні новаторські впровадження. Наукова новизна. У запропонованій статті розглянуто окремі складові процесів взаємодії українського, зокрема, закарпатського, та європейського мистецького середовища. Висвітлено складні процеси взаємодії мистецьких центрів та регіональної мистецької школи. Обґрунтовано основні засади формування новаторських ідей у контексті розвитку живопису Закарпаття першої половини XX століття. На цьому тлі окреслено основні віхи розвитку новаторських впроваджень у системі образотворчого мистецтва Закарпаття, зокрема, живопису. Розглядаючи загальномистецькі явища європейського простору, визначено окремі вагомі мистецькі події, які відбулися на території краю та за його межами, що дозволили виявити магістральні шляхи розвитку 
Conclusions. As the result of the investigation it is stated that in the first half of the XX century active exhibition movement takes place, including creative interchange which proved itself in the system of artistic and educational processes in common European area. Within the flow of such events visual art in the region went through the period of establishment and was finally formed. In this context a tendency of innovative implementations in painting of individual artists is traced. It should be mentioned that in this context separate internal and external features of ethnic romanticism can be seen. Its internal content was formed based on the background of regional traditions of folk art which became an internal reserve for creative innovations of numerous artists who worked in the region. Ethnic and cultural motives are specifically displayed in creative and methodical best practices and build up a base for works of the founders of Transcarpathian art school and first group of students. An important event which contributed to innovative solutions, was active plein-air, exhibition, artistic and educational processes. This tendency allowed to trace innovational solutions in the system of creative method for separate artists. It should be stated that a phenomenon of Transcarpathian painting school specifically stood out for its own stylistic and visual phenomenon of regional specificity of painting. Such system is built on traditions of folk culture in the region through the prism of innovative European tendencies of art.

Key words:

artist, painting, creative method, artistic area, stylistics, innovation, formalism, expressionism. новаторських рішень окремих мистецьких постатей на основі їх творчого методу. Ви-

сновки. У результаті проведеного дослідження з'ясовано, що в першій половині XX ст. відбувається активний виставковий рух, а також творчі взаємообміни, які проявили себе у системі мистецько-освітніх процесів загальноєвропейського простору. В руслі таких подій образотворче мистецтво регіону пройшло період становлення та остаточно сформувалося. В цьому контексті спостерігається тенденція новітніх впроваджень у живописі окремих мистецьких постатей. Слід стверджувати, що в цьому контексті спостерігаються окремі внутрішні та зовнішні ознаки етноромантизму. Його внутрішній зміст сформувався на тлі традицій народного мистецтва регіону, яке стало глибинним резервом для творчих новацій значної кількості митців, що працювали тут. Етнокультурні мотиви характерно відображені у творчо-методичних напрацюваннях та складають основу творчості засновників закарпатської мистецької школи та першої плеяди учнів. Вагоме явище, яке сприяло новаторським рішенням, постало в активному пленерному, виставковому та мистецькоосвітньому процесі. Така тенденція дозволила простежити інноваційні рішення у системі творчого методу окремих майстрів. Слід стверджувати, що феномен закарпатської школи живопису характерно виокремився у власне стилістично-образне явище регіональної специфіки живопису. Така система побудована на традиціях народної культури регіону в призмі новітніх європейських тенденцій тогочасного мистецтва.

\section{Ключові слова:}

митець, живопис, творчий метод, мистецький простір, стилістика, новаторство, формалізм, експресіонізм.

Вступ 1 Питання новаторства в системі дослідження мистецьких осередків та роль у цьому процесі творчих особистостей залишається відкритою і актуальною темою сучасного мистецтвознавства. Актуальною залишається проблема взаємовпливів та синтезу культур українського та загальноєвропейського простору. Подібна ситуація складається у системі стосунків у мистецького середовища Закарпаття та мистецьких центрів Мюнхена, Парижа, Будапешта, Праги у першій половині XX століття. Можна констатувати вагомий вплив таких центрів 
на загальноукраїнську структуру існуючих мистецьких шкіл. Найважливішим носієм інформації та, зокрема, новаторських тенденцій були безпосередньо творчі постаті, які доволі часто навчалися чи долучалися до мистецько-творчого загальноєвропейського руху. Яскравими представниками такого процесу в середовищі закарпатських митців стали А. Ерделі, Й. Бокшай, Ф. Манайло та інші. Зазначені художники та їх послідовники вносили новаторські ідеї в середовище мистецького простору Закарпаття, що й по цей день має вагомий потенціал для наступників, а відповідно спонукає до осмислення цілей і завдань мистецтва в контексті світоглядних й інноваційних процесів.

Мета 2
дослідження

Методологія та аналіз джерельної бази

Метою дослідження є виявлення основних тенденцій, що мали місце у процесі становлення та розвитку закарпатської школи живопису, та безпосередньо сприяли формуванню новаторства в мистецькому середовищі. Вагомим аргументом поставленої мети є узгодження загальномистецьких та культурологічних явищ цього процесу та виявлення ролі творчих постатей та їх творчо-методичних впроваджень, що можна розглядати як основу новаторських впроваджень.

У процесі дослідження стало очевидним, що окремі джерела несуть важливу, але доволі опосередковану інформацію про висунуту проблему. Окремі питання висвітлювали такі фахівці: А. Ізворин (Недзельський) (1943), А. Ерделі, Г. Островський (1974), В. Цельтнер (Павлов) (1972), О. Чернега-Балла (1978), О. Федорук, Р. Шмагало, І. Небесник (2007), І. Луценко та інші. Таким чином, було поставлене завдання вивчити та систематизувати здобутки дослідників щодо висунутої мети. Оглянувши та опрацювавши відповідні теоретичні та візуальні джерела, що містять окремі положення дослідження, було означено основні та додаткові методи дослідження. Як основні методи дослідження обрано загальнонаукові методи систематизації та історизму, розглядаючи в системі порівняльних характеристик. 3 іншого боку, було застосовано методи емпіризму та мистецтвознавчі категорії, що дозволило досягти поставлених завдань та обґрунтувати висновкові квінтесенції.

\section{Результати дослідження

Творче середовище полікультурного простору Закарпаття у межах 1920-х-1940-х рр. виокремлюється в особливу мистецько-культурну одиницю, що сьогодні розглядається як частка загальнокультурної складової українського та європейського мистецького простору. Таку модель стимулювали соціально-політичні умови, які передували цьому явищу, що визріло на підвалинах угорської мистецької освіти, зокрема. Така ситуація сприяла формуванню власної мистецької традиції, що на сьогодні вкладається у поняття Закарпатської школи живопису. Особливості становлення цього явища значною мірою сприяли дві ситуації, що склалися. Перша - політичні зміни, де 
Угорська Русь набуває статусу автономії та, відповідно, називається Підкарпатська Русь, що відбулося в значній мірі декларативно, тобто Сан-Жерменська угода від 10 вересня 1919 р., за умов якої територію краю було передано під протекторат Чехословаччини (Віднянський, 1994, с. 131). Саме в цей час культурно-мистецький простір Чехословаччини знаходився у розквіті національного відродження. Така ситуація активізувала мистецько-культурний взаємообмін, що активно сприяв формуванню індивідуальних та новаторських процесів у середовищі регіонального мистецтва і, зокрема, живопису. Зацікавлення матеріальною культурою краю з боку чехословацької інтелігенції формує образ та статус унікальності місцевого народного мистецтва. Характерною подією часу $є$ видання книги В. Маковського «Народне мистецтво Підкарпатської Русі» у 1924 р. та виставки крайового народного мистецтва у Празі (предметів побуту, вишивки, одягу, декоративно-прикладного мистецтва). Такі тенденції сприяють розвитку та формуванню культурно-мистецького осередку в краї.

Наступна ситуація, яка сприяла такому виокремленню, це мистецьке середовище з місцевих митців, тобто А. Ерделі, Й. Бокшая, Ф. Манайла, Е. Грабовського, Ю. Вірага, Д. Іяса-Яцика та інших художників, які активно працювали в містах Мукачеві, Берегові, Ужгороді, Виноградові та Хусті. Паралельно набуває активності виставковий рух в галереях Праги, Брна, Братислави, Кошиць, Будапешту, Мюнхена. Серед учасників цього руху $€$ значна частина художників, що жили і працювали в Закарпатті. Поруч з груповими відбуваються й персональні виставки, наприклад, Д. Іяса-Яцика, персональна виставка у 1925 р. в м. Братислава (Островський, 1974, с. 33), Й. Бокшай, у 1926 р. виставляється в Празі (Курильцева, 1962, с. 42) А. Ерделі, у 1923 р. в Мюнхені, виставкова зала «Скляний палац» (Небесник, 2007, с. 21). Такі можливості дозволяли митцям не тільки активно працювати, але і розкривати свій творчий потенціал з огляду на події в загальноєвропейському мистецькому просторі з його широкими стильовими ознаками.

Становлення закарпатської школи живопису полягає в тому, що мистецтво 20-х рр. XX ст. несло у собі окремі ознаки етноромантизму, що й стало вагомим аргументом «культурного відкриття» Підкарпатської Русі. Явище світової економічної кризи 1930-х рр. тільки згуртувало молоде покоління художників, які «...досконало знали народ і жили з ним одним життям... та власними практичними засобами, а в значній мірі, досвідом підняли молоде образотворче мистецтво краю на такий рівень, що дозволило визріти в самостійну школу живопису з етнонаціональними ознаками», - стверджував мистецтвознавець Г. Островський $(1974$, с. 65). Багато митців краю наслідувало принципи мистецько-освітніх здобутків угорських представників національного романтизму М. Мункачі, І. Ревеса, Ш. Голлоші, які причетні до становлення багатьох художників 
Європи, а останній став найбільш авторитетним наставником художників майже з цілого світу. Можна вважати, що подібні засади впровадження мистецьких цінностей сповідували А. Ерделі та Й. Бокшай. Ці два художники визріли у своїй творчості до практичного втілення живописних елегій на підґрунті етнічних мотивів Підкарпатської Русі.

Серед ранніх творів Й. Бокшая простежується захоплення національним романтизмом («Сільська сцена», «Жнива на полонині», «Гуцульське весілля»). У період 1920-х-1930-х рр. митця зацікавлюють теми з життя і побуту гуцулів та верховинців, про що свідчать твори не тільки цього періоду, але і продовження цього напряму в 1940-х-1960-х рр. (Чернега-Балла, 1978). Митця захоплюють як самі герої полотен, так і особливості колориту національного вбрання на тлі характерного пейзажу. Він не зосереджується на етнографічній описовості, а намагається створити узагальнений образ-картину засобом колористичних комбінацій площини та вібрації барв. Живопис Й. Бокшая характерний застосуванням засобів імпресіонізму, що відповідало логіці творчого методу, який репродукував логіку художника та спостережливість глядача (Ерделій, 1941, с. 172). Значного обсягу втілення народних типажів, а також атрибутів національного костюму гуцулів та верховинців, простежується й в сакральному живописі. В окремих пошуках він застосовує засоби стильових ознак пізнього бароко, відштовхуючись від творчості Джованні Баттіста Тьєполо та Фріца фон Уде, але в той же час, створюючи новаторський мистецький твір, який можна означити як етноромантизм живопису Закарпаття. Подібна тенденція чітко простежується у полотні «Нагірна проповідь» або «Христос серед народу» (1926р.), де оточуючий краєвид $€$ регіонально характерним, типажі зображені з слов'янськими рисами обличчя. У полотні «Притча про багатого юнака» (1936 р.) (Рис. 4.1) в образі Христа втілено символ

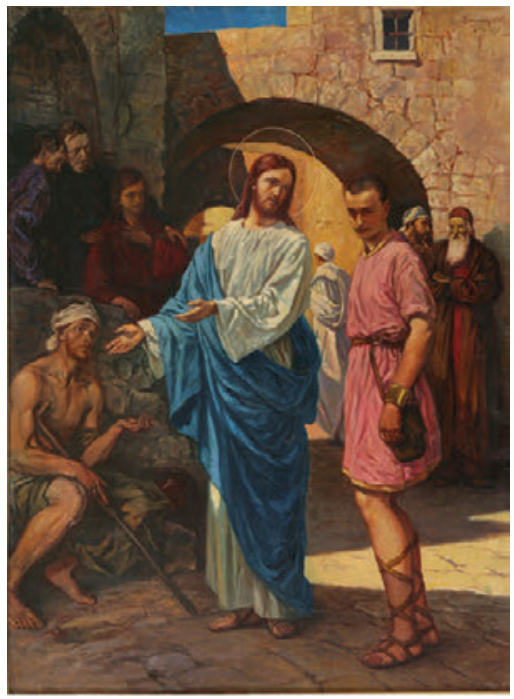

Рис. 4.1. Й. Бокшай. Притча про багатого юнака. 1936. Полотно, олія.

Fig. 4.1. Y. Bokshay. The parable of a rich young man. 1936. Canvas, oil. 
Деміург: ідеї, технології, перспективи дизайну № 2 (2018) Demiurge: ideas, technologies, perspectives of design № 2 (2018)

сакральної традиції - божественність та непорушність святині, в той же час у образі багатого юнака автор демонструє характерний місцевий типаж юнака.

Враховуючи експресіоністичний живописний підхід А. Ерделі, він знаходить засоби та методи відтворення етнічних тем, які абсолютно вкладаються у його образотворчі засади. Для автора вагомими стали не форми сучасного мистецтва, а власні творчо-методичні рішення, які він зміг застосувати у власній живописній манері, залишаючись підкарпатським художником[11,9]. В окремих випадках автор демонструє твори, які близькі до жанрової картини «Святковий день. На Русаля» (1933 р.), «Біля річки» (1930-і рр.), створює значну кількість портретів у народному костюмі «Дівчина в червоній хустині» (1930-і рр.), «Верховинка» (1947р.), «Молодиця» (1940-і рр.). У цих полотнах виразно простежуються сформований, власний творчий метод та ідеї новаторських прийомів, де жанрова домінанта переходить вагомість представленої ідеї - картинного образу. Окремо А. Ерделі демонструє в експресивному ключі традиційну символіку народного костюму, також демонструючи новаторські підходи. Слід зазначити те, що подібні принципи стають аксіомою в мистецько-педагогічній діяльності. Підтвердженням цього є живописні твори молодого покоління закарпатських художників А. Коцки, Е. Контратовича, А. Борецького, В. Дван-Шарпотокі та інших. А. Ерделі, був переконаний в необхідності формування індивідуальної, регіональної мистецької школи, яка повинна розвиватись на власних традиціях. «Мистецтво майже всіх країн має свої направляючі, котрі ведуть за собою нову генерацію» - стверджував митець (Ерделій, 1941, с. 169). В цьому випадку А. Ерделі абсолютно впевнений у власній місії щодо створення мистецької школи та необхідності формування творчого осередку однодумців. Концептуальними принципами, які б змогли дати можливість об'єднатися митцям, стали ознаки народної поліетнічної культури Закарпаття, зокрема, ландшафтна специфіка та ії кольорові дефініції. Про це художник констатує у звіті «Доклад о дђеяльности Унгварского кор. Греко-кат. лицея пђвцо-учит. Семинаріђ за 1938/39 школьный рок. Подає д-р Ернест Дунда, доч. директор», в якому автор констатує основоположні засади об'єднання митців, що засноване у 1931 р. як «Товариство діячів образотворчого мистецтва Підкарпатської Русі», одним із основних завдань якого стало згуртування творчої молоді. Кінцевою метою об'єднання було створення мистецького центру та сприяння покращенню умов для творчої роботи (Фекета, 1996). Наміри, які прозвучали від представника державного освітнього закладу, в якому працювали А. Ерделі та Й. Бокшай, свідчили про широку підтримку не тільки митців, але й культурного життя регіону в цілому. Очевидно, така підтримка та сприяння розвитку мистецької освіти на Підкарпатській Русі дозволяли у 1927 р. відкрити недільно-суботню «Публічну школу рисунку», яка існувала на базі зга- 
даної семінарії під керівництвом А. Ерделі та Й. Бокшая. Слід зазначити про високий методично-педагогічний рівень школи, де студенти вивчали не тільки спеціальні предмети - рисунок, живопис, композицію, але також і допоміжні дисципліни перспективу, історію мистецтв, пластичну анатомію (Садварі, 1981). Така тенденція підходів до мистецько-освітнього процесу свідчить про ґрунтовні наміри щодо створення умов навчання, які відповідали засадам європейської мистецької освіти на прикладі Будапешта, Мюнхена, Праги та Парижа.

Результат мистецько-освітньої праці продемонструвала плеяда учнів, яка власними здобутками засвідчила рівень викладацької роботи А. Ерделі та Й. Бокшая. На перших спільних виставках можна було простежити творчі досягнення молодих учнів школи А. Коцки, А. Борецького, Е. Контратовича, А. Добоша. У 1935 р. А. Коцка в Ужгороді відкриває свою першу персональну виставку, яка викликала захоплення не тільки в глядачів, але й позитивні відгуки його вчителів. Художник до цієї виставки готувався, перебуваючи на посаді сільського вчителя в с. Тихе на Верховині (Изворин, 1943, с. 273). Уже в 1939 р. А. Коцка разом зі своїми колегами та вчителями приймає участь у всеугорському пленері та згодом - виставці в м. Кошіце. Згадуючи у своїй публікації в газеті «Русская правда» про пленер, який передував самій виставці, де учасниками були багато іменитих угорських митців, художник пише: «Наш край дає багато матеріалу для творчості... якщо би нам (Підкарпатським художникам авт.) вдалося відтворити не тільки зовнішньо, але і душу Верховини, то виникне своєрідне підкарпатське мистецтво» (Коцка, 1939). Думку А. Коцки згодом підтверджує та доповнює угорський мистецький критик Ернест Каллаї, який наголошує на своєрідності закарпатського живопису та влучно констатує його концептуальну сутність, вважаючи що художники застосовують у творчості здобутки «образотворчої свободи» європейського мистецтва з метою заглиблення в сутність природи та людей регіону (Каллаи, 1940, с. 36). Відомо, що окремі аналітичні факти угорського мистецтвознавця, а також окремі напрацювання творчого осередку митців Закарпаття означують індивідуальні засадні принципи «новітнього» живопису регіону, які виражені особливістю творчого методу на основі етноромантичних традицій. Про це засвідчує значна кількість живописних творів, виконаних А. Коцкою, А. Борецьким, Е. Контратовичем, А. Добошом, В. Дван-Шарпотокі, а також ї наставниками А. Ерделі та Й. Бокшаєм.

Під протекторатом президента Чехословаччини Едварда Бенеша у 1937 р. відбулася групова виставка в Празі «Slovtnsko a Podkarpatska Rus», особливою рисою якої була присутність молодої групи митців, а також вчителів з Ужгорода та Мукачева. Художники виставили переважно живописні полотна, в яких втілено характерні ознаки етнічної культури та краєвиду регіону (Wagner, 1937). Вагомість проведення виставки засвід- 
Деміург: ідеї, технології, перспективи дизайну № 2 (2018) Demiurge: ideas, technologies, perspectives of design № 2 (2018)

чує патронатство вищої особи краю. Відомий чеський критик д-р. В. Вагнер пише вступне слово до упорядкованого до виставки каталогу. Тут він зазначає, що живопис Підкарпатської Русі виокремлюється у власне мистецьке явище, яке шукає притаманну тільки йому духовну виразність (Wagner, 1937). Особливість представлення етнічних тем торкається майже усього загалу явищ, що, зокрема, пов'язані з народним мистецтвом і традиціями Закарпаття. Художники втілюють ідеї майже в усіх жанрових напрямах, використовуючи різні технічні засоби, втілюючи новітні творчі рішення. Зокрема, А. Ерделі намагається створити експресивний образ самого твору, використовуючи для цього портрет із середовища підкарпатського села та народний костюм, пейзаж та атрибути побуту, що простежується у творах «Гуцул із люлькою» (середина 1930-х рр.), «Пейзаж з річкою» (1930-і рр.) (Рис. 4.2), «Дівчата на річці» (1940-і рр.) та ін.

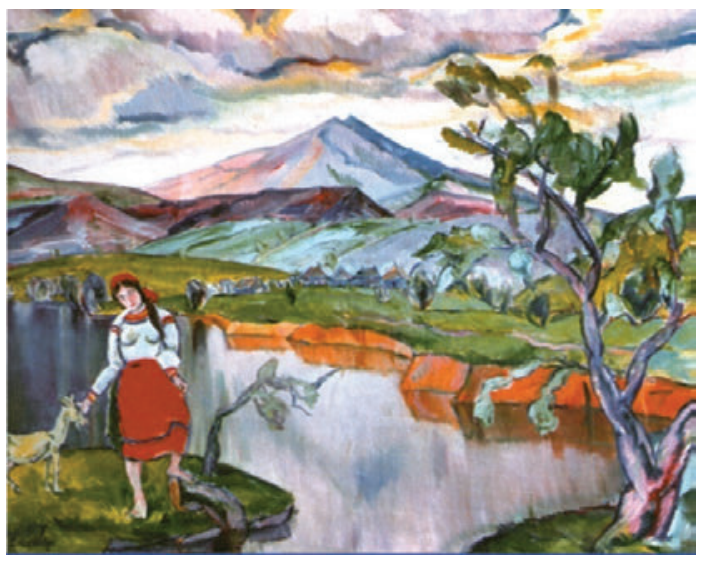

Рис. 4.2. А. Ерделі. Пейзаж з річкою, 1930-ті. Полотно, олія.

Fig. 4.2. A. Erdeli. Landscape with the river, 1920-s. Canvas, oil.

Творчо-методичні прийоми Й. Бокшая демонструють його прихильність до імпресіоністичних впроваджень національної теми гуцулів та верховинців. Художник вбачає навіть у самому народному костюмі прояви імпресіонізму, які митець таким способом і відтворює, зберігаючи достовірність завдяки реалістичній манері виконання («Гуцульське весілля» (1930-ірр.), «Колядники» (1930-ірр.) «Збір яблук» (1925 р.), «Дівчата на полонині» (1937 р.)), та особливої динаміки розвитку тема знаходить у 1940-х - 1950-х рр. («Гуцулка» (1926 р.), «Бокораші» (1960 р.) (Чернега-Балла, 1978)).

Тема народного мистецтва та легенд абсолютно вкладається у творчість Ф. Манайла та навіть більше того: вона захоплює автора чи не найглибше. Художник у формі експресіонізму та символізму намагається побудувати образи живописного втілення народної усної творчості у формі казок чи бувальщин. Значне місце у творчості автора посідають народні та релігійні свята, які він висвітлює, намагаючись відтворити не тільки манеру виконання народного майстра, але й передати в цьому 
філософський зміст, зокрема, це простежується у творах «Помиванки» (1940р.), «Комора. Сіни» (1937 р.), що також продовжується в більш пізніх напрацюваннях автора - «Зустріч молодих» (1976 р.), «Мисливець» (1976 р.).

Окрім згаданих художників, до народної теми в регіоні апелюють угорські, чеські та словацькі майстри, які також входили до товариства підкарпатських митців або час від часу брали участь у виставках разом із членами товариства. 3 особливим захопленням в цьому напрямку працює Д. Ендреді. Художник, угорець за походженням, народився в м. Мукачеві (1910р.), після закінчення Будапештської академії мистецтв повертається до Закарпаття та активно долучається до роботи товариства підкарпатських митців. Хоча і не довгий час митець тут працює, але переймається, як пише дослідник мистецтва А. Ізворин, «підкарпатською темою». У його творах звучать ліричні мотиви русинського села, героями творів стають лісоруби, жінки на полі, що пораються з сіном. Роботи виконані та витримані у візантійсько-іконній манері двовимірності, оминаючи зовнішню етнографічність у відтворенні народного костюму (Изворин, 1943, с. 277). Художник у числі учасників вищезгаданої виставки 1939 р. представляє твір «Русинський селянин». Більшість його творів того періоду на сьогодні $€$ невідома, ймовірно, вони знаходяться в угорських збірках, оскільки до середини 1940-х художник виїхав до Угорщини.

Значний внесок у розвиток та популяризацію підкарпатського живопису в першій половині XX століття зробили педагоги, культурні діячі та художники Чехословаччини в період 1919-1939 рр. Визначити роль певних професійних преференцій складно, оскільки у багатьох випадках персоналії вдало абсорбували у собі багато задатків, зокрема, малярство. Прикладом був Ладіслав Кайгл - особистість, яка поєднувала в собі педагога, громадського діяча, а також художника. До списку можна віднести також окремих персоналій, переважно з фаховою мистецькою освітою: Я. Заїчека, М. Лудву, О. Бедржіха, Й. Томашека, О. Єлена. Переважно, вони були й першими учасниками товариства підкарпатських митців (1931р.). Особливо цікавими є живописні рішення О. Єлена (професор рисунку в Ясінянській деревообробній школі), який у системі динамічних експресій створив «Гуцульське весілля» чи «Ясінянський пейзаж» (Рис. 4.3), що технічно є характерною ознакою європейських новаторських експериментів.

Захоплення народною темою простежується у живописі та графіці чеських митців В. Фіали та Л. Куби. Водночас, складно порівняти ці дві особистості у змісті застосування творчо-методичних засобів, але кожен із них знайшов для себе багатогранну тему в народно-мистецьких проявах матеріальної культури гуцулів та верховинців. Подібні пошуки та способи організаційних принципів між художниками дозволили розширити поле напрацювань у творчо-методичній доктрині кожного, і в той же 
Деміург: ідеї, технології, перспективи дизайну № 2 (2018)

Demiurge: ideas, technologies, perspectives of design № 2 (2018)

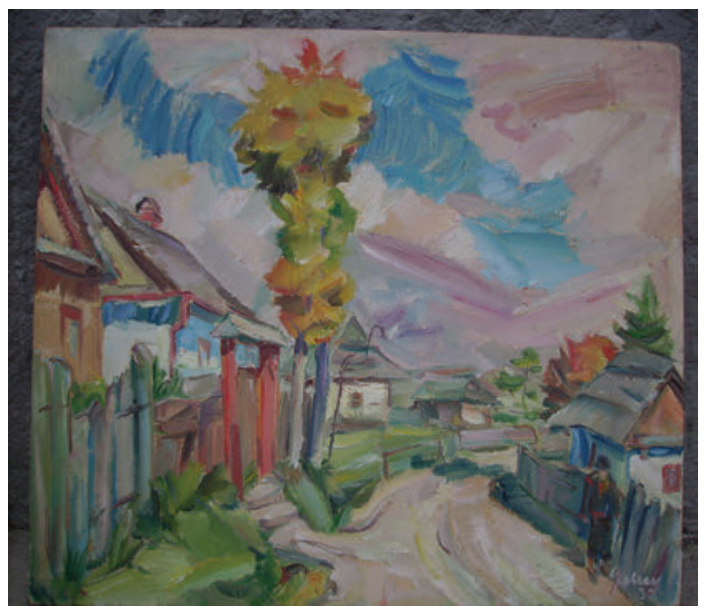

Рис. 4.3. Є. Отто. Сільська вулиця. 1937. Полотно, олія.

Fig. 4.3. E. Otto. Rural street. 1937.

Canvas, oil.

час створювати можливості новітніх впроваджень у середовищі мистецького простору Європи завдяки творчим виставкам та пленерам.

\section{Наукова новизна та практичне значення дослідження \\ 5}

у запропонованій статті розглянуто окремі складові процесів взаємодії українського, зокрема, закарпатського та європейського мистецького середовища. Висвітлено складні процеси взаємодії мистецьких центрів та регіональної мистецької школи. Обґрунтовано основні засади формування новаторських ідей у контексті розвитку живопису Закарпаття першої половини XX століття. На цьому тлі окреслено основні віхи розвитку новаторських впроваджень у системі образотворчого мистецтва Закарпаття, зокрема, живопису. Розглядаючи загальномистецькі явища європейського простору, визначено окремі вагомі мистецькі події, які відбулися на території регіону та за їі межами, що дозволили виявити магістральні шляхи розвитку новаторських рішень окремих мистецьких постатей на основі їх творчого методу.

Висновки $\mathbf{6}$

У результаті проведеного дослідження з'ясовано, що в першій половині XX ст. відбувається активний виставковий рух, а також - творчі взаємообміни, які проявили себе у системі мистецько-освітніх процесів загальноєвропейського простору. У руслі таких подій образотворче мистецтво регіону пройшло період становлення та остаточно сформувалося. В цьому контексті спостерігається тенденція новітніх впроваджень у живописі окремих мистецьких постатей. Слід стверджувати, що в цьому контексті спостерігаються окремі внутрішні та зовнішні ознаки етноромантизму. Його внутрішній зміст сформувався на тлі традицій народного мистецтва регіону, яке стало глибинним резервом для творчих новацій значної кількості митців, що працювали в регіоні. Етнокультурні мотиви характерно відображені у творчо-методичних напрацюваннях та складають основу творчості засновників закарпатської мистецької школи 
та першої плеяди учнів. Вагоме явище, яке сприяло новаторським рішенням, постало в активному пленерному, виставковому та мистецькоосвітньому процесі. Така тенденція дозволила простежити інноваційні рішення у системі творчого методу окремих майстрів. Слід стверджувати, що феномен закарпатської школи живопису характерно виокремився у власне стилістично-образне явище регіональної специфіки живопису. Така система побудована на традиціях народної культури регіону в призмі новітніх європейських тенденцій тогочасного мистецтва.

\section{Список посилань}

Віднянський, С. (1994). Закарпаття у складі Чехословацької республіки: переломний етап у національно-культурному й етнополітичному розвитку русинів-українців. В Культура Українських Карпат (с. 130-140). Ужгород: Гражда.

Ерделій, Б. (1941). Унгварські художні тижні. Зоря-Hojnal, 1 (1-2), 168-176.

Изворин, А. (1943). Сучасні руські художники. Зоря-Hajnal, 3 (1-4), 258-284.

Каллаи, Э. (1940). Искусство и художники Карпатского края. В Огоньки (Декабрь, с. 35-39). Ужгород

Коцка, А. (1939). К выставке картин «Общества угрорусских художников». Русская правда, 44. Курильцева, В. (1962). Бокшай Иосиф Иосифович. Москва: Советский художник.

Небесник, І.І. (2007). Адальберт Ерделі. Львів.

Островський, Г. (1974). Образотворче мистецтво Закарпаття. Київ.

Павлов, В. (1972). Адальберт Ерделі. Київ: Мистецтво.

Садварі, В. (1981, 23 травня). Живописець чистої води. Прапор перемоги.

Фекета, І. (1996, 25 травня). Адальберт Ерделі у пам'яті учнів. Новини Закарпаття.

Чернега-Балла, О. (1978, 16 вересня). Краса відкрита всім. Закарпатська правда.

Wagner, V. (1937). Slovensko a Podkarpatská Rus, jejich lid a kraj ve výtvarném umění: Výstava Československé jednoty od 29. ledna do 23. února v pavilonu Myslbeka Praha 1, Na Př́kopě. Praha : Československá jednota.

\section{References}

Cherneha-Balla, O. (1978, September 16). Krasa vidkryta vsim [Beauty is open to all]. Zakarpatska Pravda [in Ukrainian].

Erdelii, B. (1941). Unhvarski khudozhni tyzhni [Hungarian art weeks]. Zoria-Hojnal, 1 (1-2), 168-176 [in Ukrainian].

Feketa, I. (1996, May 25). Adalbert Erdeli u pam'iati uchniv [Adalbert Erdeli in the memory of the disciples]. Novyny Zakarpattia [in Ukrainian].

Kallai, E. (1940). Iskusstvo i hudozhniki Karpatskogo kraya [Art and artists of the Carpathian region]. In Ogonki [Lights] (December, pp. 35-39). Uzhgorod [in Russian].

Kotska, A. (1939). K vyistavke kartin "Obschestva ugro-russkih hudozhnikov" [For the exhibition of paintings by the Society of Ugro-Russian Artists]. Russkaya pravda, 44 [in Russian].

Kuriltseva, V. (1962). Bokshay losif losifovich. Moscow: Sovetskiy hudozhnik [in Russian].

Nebesnyk, I.I. (2007). Adalbert Erdeli. Lviv [in Ukrainian].

Ostrovskyi, H. (1974). Obrazotvorche mystetstvo Zakarpattia [Fine Arts of Transcarpathia]. Kyiv [in Ukrainian].

Pavlov, V. (1972). Adalbert Erdeli. Kyiv: Mystetstvo [in Ukrainian].

Yzvoryn, A. (1943). Suchasni ruski khudozhnyky [Contemporary Russian artists]. Zoria-Hajnal, 3 (1-4), 258-284 [in Ukrainian]. 
Деміург: ідеї, технології, перспективи дизайну № 2 (2018)

Demiurge: ideas, technologies, perspectives of design № 2 (2018)

Sadvari, V. (1981, May 23). Zhyvopysets chystoi vody [Painter of pure water]. Prapor peremohy [in Ukrainian].

Vidnianskyi, S. (1994). Zakarpattia u skladi Chekhoslovatskoi respubliky: perelomnyi etap u natsionalno-kulturnomu y etnopolitychnomu rozvytku rusyniv-ukraintsiv [Transcarpathia within the Czechoslovak Republic: a turning point in the national-cultural and ethnopolitical development of Rusyn-Ukrainians]. In Kultura Ukrainskykh Karpat [Culture of the Ukrainian Carpathians] (pp. 130-140). Uzhhorod: Hrazhda [in Ukrainian].

Wagner, V. (1937). Slovakia and the Sub-Carpathian Rus, their People and the Region of Fine Arts: Exhibition of Czechoslovak Unity from 29 January to 23 February in the Myslbek pavilion. Prague: Czechoslovak Unity [in Czech]. 